\title{
Women Travellers as Consumers: Adoption of Modern Ideas and Practices in 19th-Century Southeast Europe
}

\author{
Evguenia Davidova
}

... although I have never left Sofia before,

I believe that I will learn how to live in other places. ${ }^{1}$

The epigraph to this chapter is an excerpt from a letter written in 1862 by the Bulgarian philanthropist and activist Iordanka Filaretova (1843-1915), the wife of a Russian civil servant, before travelling to Constantinople (Istanbul). ${ }^{2}$ She addressed a friend who had already visited the city and described to her its splendours. The quote captures the prospects of spatial mobility that opened to educated middle-class women and their responsiveness to such new opportunities. Women's travel in the 19th century was still quite limited with the exception of teachers, pilgrims, Greek diaspora women, some merchants' wives, and the spouses of new professionals, such as engineers and doctors. Filaretova's later trips and deeds in the Ottoman Empire and Russia certified her keenness to adopt new ideas. For instance, after living in Constantinople between 1862-1867, she moved back to Sofia where she was among the initiators of a women's society $(1869) .^{3}$

This chapter explores various case studies of women travellers who traversed the Ottoman Empire, the Balkan states, Russia, and other European countries in the course of the long 19th century. It also pays attention to ways of adopting and disseminating material objects, services, and ideas as part

1 Bulgarian Historical Archive at the National Library "Sts. Cyril and Methodius", hereafter (BIA-NBKM), f. 22, a.e. 9o, p. 1. Iordanka Filaretova to Maria Gerova, 17 May 1862. All translations, unless otherwise indicated, are mine.

2 Both names are used interchangeably throughout the text.

3 Khristo Tsekov, Iordanka Filaretova Gospozhata (Sofia: 2009), 54. 
of diverse consumption practices. I suggest that women's physical mobility, a form of consumerism in its own right, not only exposed them to different lifestyles, but also offered them novel ways of constructing gender and class identity. Both travel and consumption were intimately related to the market and women's exposure to the expanding commodification of culture (with an emphasis on progress) fostered a cultivation of new modern sensibilities and secular perceptions.

Since the 1990s, when Jan de Vries introduced the notion of "industrious revolution", researchers have argued in favour of the centrality of consumption to modern identity construction. ${ }^{4}$ Alongside studies on homo faber, homo economicus, and other "men", scholars began research on homo edens, the consumer, and showed how the world of goods shaped men and women. ${ }^{5}$ Moreover, the "gendering and the meanings of bourgeois consumption" changed throughout the 19th century. ${ }^{6}$ It was also in the 1990s when the cultural approach "reached" the Balkan national historiographies and class began to be interpreted as a broad "set of cultural relations" interwoven with other categories, such as gender, perceptions and representations, daily practices, and human agency. ${ }^{7}$ There were multiple meanings of consumption that were negotiated and appropriated by different groups within specific contexts. ${ }^{8}$ Thus, gendered consumption became an integral part of asserting not only middleclass lifestyles, but also a tool for exercising social influence within and across various ethno-confessional communities.

4 Earlier research paid more attention to the "exchange of values" as a politically mediated process. See, for example, Arjun Appadurai (ed.), The Social Life of Things: Commodities in Cultural Perspective, (Cambridge: 1986), 4-6. More recent scholarship focused on both social and gender aspects. See Victoria de Grazia and Ellen Furlough (eds.), The Sex of Things: Gender and Consumption in Historical Perspective (Berkeley: 1996); Mary Louise Roberts, "Gender, Consumption, and Commodity Culture", The American Historical Review 103, no. 3 (Jun.,1998): 817-844. For the Ottoman Empire, see Donald Quataert, (ed.), Consumption Studies and the History of the Ottoman Empire 1550-1922. An Introduction (New York: 2000).

5 John Brewer and Roy Porter, “Introduction”, in John Brewer and Roy Porter (eds.), Consumption and the World of Goods (London: 1993), 3.

6 Leora Auslander, "The Gendering of Consumer Practices in Nineteenth-Century France", in The Sex of Things: Gender and Consumption in Historical Perspective, 79.

7 Thomas Gallant, "Long Time Coming, Long Time Gone: The Past, Present and Future of Social History", Historein, 12 (2012): 12-13; Yannis Yannitsiotis, "Social History in Greece: New Research on Class and Gender", East Central Europe 34, no. 1-2 (2007): 105-138.

8 Haris Exertzoglou "The Cultural Uses of Consumption: Negotiating Class, Gender, and Nation in the Ottoman Urban Centers during the 19th Century", International Journal of Middle East Studies 35 (2003): 77 . 
Most research on travel has been focused on western travellers visiting the Balkans, either within the framework of Orientalism, Balkanism, or both. Only recently, a few studies have "reversed" the gaze and explored the agency of "travellers from the region, and not only to [emphasis in the original] it". Moreover, Wendy Bracewell has coined the felicitous neologism-domopis (homeland writing) - travel accounts from within that encompass both ideological and entertaining functions. ${ }^{10}$ In this chapter, I will discuss the itineraries and interactions of women who lived in the Ottoman Empire and the Balkan states, and their travels both within and outwith the region. Whenever appropriate, I will refer to comparisons with well-known foreign women travellers.

Western female travel writing on the Balkans has a meagre tradition exemplified mostly by the 18th-century travels of Lady Mary Wortley Montagu $(1716-1718)$ and of Lady Craven (1785-1786), both written in epistolary form. They established an aristocratic tradition of the Grand Tour in seeing themselves as members of a superior culture who either described the picturesque landscape and pristine peasant life or saw women in the Ottoman Empire as freer than their European counterparts. ${ }^{11}$ In the 19th century, middle-class women such as Georgina MacKenzie and Adeline Irby, influenced by Victorian philanthropy, set off to educate the oppressed Slav population, defying the official British policy of support for Ottoman integrity. They, together with the Russian M[aria] Karlova and the Briton Mary Adelaide Walker, ventured to cross cultural borders, but not class boundaries. They all claimed to be free in their choice of visits and asserted singularity through the ability to enter baths, harems, and houses. ${ }^{12}$ In doing so, they continued the female writing tradition of "desexualizing" the harem and expanded the travel narrative by penetrating

$9 \quad$ Wendy Bracewell and Alex Drace-Francis, (eds.), Balkan Departures. Travel Writing from Southeastern Europe (New York: 2009), 5; Wendy Bracewell (ed.), Orientations. An Anthology of East European Travel Writing, ca. 1550-2000 (Budapest: 2009).

10 Wendy Bracewell, "Travels Through the Slav World", in Wendy Bracewell and Alex DraceFrancis (eds.), Under Eastern Eyes: A Comparative Introduction to East European Travel Writing on Europe (Budapest: 2008), 192-194; Id., Orientations, XVII, 129.

11 On comparisons between both travellers, see Efterpi Mitsi, "Lady Elizabeth Craven's Letters from Athens and the Female Picturesque", in Vassiliki Kolocotroni and Efterpi Mitsi (eds.), Women Writing Greece. Essays on Hellenism, Orientalism and Travel (Amsterdam: 2008), 19-37; On aristocratic women travellers who preceded Lady Craven's journey, see Matei Cazacu, Des Femmes sur les routes de l'Orient. Le voyage à Constantinople au XIX $X^{e}$ siècle (Genève: 1999), 7-30.

12 Evguenia Davidova, "Gender and Culture in the Turkish Province: The Observations of a Russian Woman Traveler (1868)", Aspasia 6 (2012): 79-95. 
the family private sphere. ${ }^{13}$ Yet, they still maintained a distance from the local conditions.

By contrast, Balkan women teachers, merchants' and professionals' wives left less dramatic, but nonetheless significant impressions from their travels and evidence about how those experiences transformed their daily lives. Selected case studies will be examined to interpret social transformations within a multiethnic and national framework. One group of women kept diaries, such as Natalija Matić Zrnić (1880-1956), a Serbian teacher married to a railway engineer, who followed her husband's peripatetic life, living in Arandjelovac, Paraćin, Čuprija, Valjevo, Šabac, and Vranje between 1904-1911. ${ }^{14}$ Ekaterina Karavelova (186o-1947), who travelled in Russia, Bulgaria, Europe, and America, was a teacher, translator, diarist, and the wife of the three-time Bulgarian prime minister. ${ }^{15}$ Another set of women wrote autobiographies or memoirs. This group includes Rada Kirkovich (1848-1941), a Bulgarian teacher and doctor's wife who studied and lived in Russia, the Ottoman Empire, and Bulgaria; ${ }^{16}$ and Anastasia Tosheva (1837-1919), married to a merchant, who also studied in Russia and then became a teacher in many towns of the Ottoman Empire and independent Bulgaria. ${ }^{17} \mathrm{~A}$ third group of women travellers who produced diverse correspondence comprises the aforementioned Filaretova, and Sotiria Cléoménous-Alibertis (1847-1929), a Greek teacher, journalist, and deputy-principal of the private school for girls, Zappeion, in Constantinople, who travelled across southeast Europe on her own or accompanying her husband. ${ }^{18}$

13 Billie Melman, "Desexualizing the Orient: The Harem in English Travel Writing by Women, 1763-1914", Mediterranean Historical Review 4, no. 2 (December 1989), 313.

14 Jill A. Irvine and Carol S. Lilly (eds.), Natalija. Life in the Balkan Powder Keg, 1880-1956 (Budapest: 2008), 1-21.

15 Ekaterina Karavelova, Spomeni na Ekaterina Karavelova (Sofia: 1984); Fani Drenkova, comp. Kato antichna tragedia. Sŭdbata na Ekaterina Karavelova i neinoto semeistvo v pisma, dnevnitsi, fotografia (Sofia: 1984).

16 Rada Kirkovich, Spomeni (Sofia: 1927).

17 Anastasia Tosheva, Avtobiografia (Stara Zagora: 1911).

18 Efi Kanner, Emphyles koinonikes diekdikiseis apo tin Othomaniki autokratoria stin Ellada kai stin Tourkia. O kosmos mias ellinidas christianis daskalas (Athens: 2012); Efi Canner, "Embourgeoisement, réseaux sociaux et identitiés de genre dans les Balkans de la deuxième moitié du XIX ${ }^{\mathrm{e}}$ siècle. Le cas de Sotiria Cléoménous-Alibertis", Turcica 39 (2007), $175^{-199 .}$ 
Others, like Jelena Dimitrijević (1862-1945), the wife of a Serbian officer, was a feminist writer and journalist who published a travelogue in epistolary form. ${ }^{19}$ She followed her husband's military career and lived in Niš, Kraljevo, and Pirot until they settled in Belgrade. Later in life she visited India, Egypt, and America. Lastly, a few women published travelogues in English for European audiences. Such was the case of the Greek Demetra Vaka (1877-1946), a novelist and journalist, who visited Albania, Montenegro, Serbia, Bulgaria and Greece in 1898 while accompanying her brother, who had been sent by the Ottoman government to inspect the region. ${ }^{20}$ Similarly, Melek Hanım (1816/1818-1873), a Levantine of Greek, Armenian, and French origin, was one of the wives of Kabrizlı Pasha, three times grand vizier, and travelled with him in many provinces of the Ottoman Empire. ${ }^{21}$ Lastly, Halidé Edib (1884-1964), daughter of an Ottoman high official, was a teacher, translator, journalist, and writer who worked in Syria and Lebanon and later lived in England and France. In order to "reach the world", she decided to write her memoirs in English. ${ }^{22}$ In other words, most of those women travelled to study, teach in various localities, or follow the peripatetic life of their husbands.

This chapter is organized around three main themes: the relationship between travel and material consumption; channels of change; and social perceptions of the "woman question". It draws on a variety of primary sources and proposes to read travel experiences not only through nationalist lenses, but also through the notion of shared social space where dynamic exchanges and consumer practices, both old and new, were produced and re-constituted in fluid social milieus. The chapter addresses two different, yet interrelated issues, and shows how women travellers described the local societies and how they interacted with or intervened in local contexts. By bringing together travel and gender as categories of analysis, with this chapter, I join the conversation that has identified consumption as central to multiple social changes and complex

19 Jelena Dimitrijević, Pisma iz Soluna/Epistoles apo ti Thessaloniki, eds. Dejan Aničić and Vladimir Bošković (Lozniza: 2008); See also Celia Hawkesworth, "A Serbian Woman in a Turkish Harem: The Work of Jelena Dimitrijević (1862-1945)”, The Slavonic and East European Review 77, no. 1 (Jan., 1999): 56-73.

20 Demetra Vaka (Mrs. Kenneth-Brown), The Heart of the Balkans (Boston: 1917).

21 One should bear in mind that her so-called memoirs are considered to be highly fictionalized. Melek Hanım, Thirty Years in the Harem; or, the Autobiography of Melek-Hanum, wife of H. H. Kibrizli-Mehemet-Pasha (New York: 1872).

22 The book was originally published in English in 1926 and appeared in Turkish in 1955 and 1963. Halidé Edib, House with Wisteria. Memoirs of Halidé Edib (Charlottesville: 2003), XII-XIII. 
transitions: rural/urban, illiterate/literate, pre-industrial/industrial, empire/ nation-states, religion/secularism, subjects/citizens, and pre-modern/modern.

\section{Material Consumption and Travel}

Vivid descriptions of houses, shops, and hotels were a standard staple in most western travelogues, written by both male and female voyagers. For example, the seasoned traveller Mary Walker made the following comment: "Travellers accustomed to the luxurious hotels of civilized Europe, can form no idea of what must be endured in the search after the picturesque in the interior of Turkey."23 Along the same lines, most of M[aria] Karlova's remarks were related to material markers of what she perceived as European expressions of progress and modernity, such as furniture, female attire, hairstyles, home frontages, shops, and various commodities. For instance, in Ottoman Macedonia, "Almost everywhere the Hoffman drops [bottles] decorate the shelves of the Bulgarian and Albanian hans [inns] and their German labels are the only representatives of European culture." 24

Some Balkan women travellers internalized this patronizing attention to visible signs of western material objects and services as a criterion to justify or reject degrees of modernization and progress. Thus, Demetra Vaka wrote about Serbia: "The standards, the attitude toward life, even the material comforts were of a different world. It was the Balkans still, far behind the rest of Europe." ${ }^{25}$ Similarly, Melek Hanım described Belgrade in the 186 os in condescending materialistic terms: "Belgrade then was an ill-built town; its streets were narrow, dirty, and ill-paved. The shops were numerous, but they offered no attractions." ${ }^{26}$ Ekaterina Karavelova also shared the discomfort she experienced after returning from Moscow to her native town where there were no European amenities. Consequently, the next morning, she bought a bed, table, mirror, and "three Viennese chairs". ${ }^{27}$ These quotes equate progress and

\footnotetext{
23 Mary Adelaide Walker, Through Macedonia to the Albanian Lakes (London: 1864), 86.

24 M. Karlova, “Turetzkaya provintziya", Vestnik Evropȳ 5, no. 3 (1870), 731.

25 Vaka, The Heart, 110. On Vaka's complex identity, who wrote as an orientalist writer but also subverted the genre, see Duygu Köksal, "Escaping to Girlhood in Late Ottoman Istanbul: Demetra Vaka's and Selma Ekrem's Childhood Memories", in Benjamin C. Fortna (ed.), Childhood in the Late Ottoman Empire and After (Leiden: 2016), 250-274.

26 Melek Hanım, Thirty Years, 111.

27 Karavelova, Spomeni, 62-63; Drenkova, Kato antichna tragedia, 54-55.
} 
modernity with timid consumption of products representative of European lifestyles.

When other women from southeastern Europe travelled, they also expressed concerns related to the material comforts of daily life..$^{28}$ For instance, Natalija Zrnićs diary reveals how the expanding urban middle class paid close attention to possessions at the turn of the century. When Zrnić moved to study in Belgrade, she described her aunt's apartment as consisting of "two clean and sunny rooms, with a kitchen and shed some distance away". Later, she noted the changes she made in her own home in Valjevo: "I picked up and cleaned the guest room in preparation for the slava celebration. We're in the process of painting the kitchen." ${ }^{29}$ Jill Irvine and Carol Lilly commented on these social transformations in the context of "separate sphere": "As men moved into the wage labor force, middle-class women were increasingly confined to the private sphere of the home, where they were expected to maintain order, create a pleasant atmosphere, and pass on important national and family traditions and values." ${ }^{30}$ Although women's material consumer habits have been highly criticized by contemporaries, this phenomenon cannot be divorced from the consumption of their husbands, children, and households. ${ }^{31}$

Similar pride in keeping "managerial status within the home"32 is evidenced in the correspondence of Rada Kirkovich. She wrote to her aunt from the Orlov area in Russia where her husband worked as a doctor: "We are preparing for the winter and workers covered with oilcloth all the furniture: 2 big divans, 8 armchairs, 15 chairs, 5 tables. All the housework, including cleaning, laundry, and cooking, was done by the maids." The mention of servants was an important attribute of bourgeois status. She also shared: "Now I have a cookbook and sometimes I prepare new meals on the Russian stove." ${ }^{33}$ As others noted, domestic consumption - that of the family's daily interaction with the market - was mainly a female responsibility. ${ }^{34}$ Moreover, the Kirkovichs' lifestyle included regular social interactions with the local gentry (pomeshchiks). ${ }^{35}$

28 In 18th-century England the notion of comfort became a middle ground between necessity and luxury. Joyce Appleby, "Consumption in Early Modern Social Thought", in Consumption and the World of Goods, 169.

29 Irvine and Lilly, Natalija, 43, 67.

3o Irvine and Lilly, Natalija, 17.

31 Amanda Vickery, "His and Hers: Gender, Consumption and Household Accounting in Eighteenth-Century England", Past and Present (2006) Supplement (Vol. 1), 35.

32 Auslander, "The Gendering of Consumer Practices", 83.

33 BIA-N вкм, f. 22, a.e. 886, p. 14-15. Rada Kirkovich to Maria Gerova, 16 September 1876.

34 Carol E. Harrison, The Bourgeois Citizen in Nineteenth-Century France. Gender, Sociability, and the Uses of Emulation (Oxford: 1999), 13. 
These examples suggest a close connection between home management and class sociability through consumption of material objects. In contrast to the above-cited western travellers, these travelling women paid attention to possessions, family property, and middle-class status as a daily occurrence, not as an exotic anecdote or a civilizational achievement. ${ }^{36}$

Another widespread form of material consumption concerns female attire. During their schooling abroad, many female students acquired modern cultural habits, such as a taste for fashionable clothing, home furnishings, and leisure activities. For instance, Kirkovich wrote about her first visits to Shakespeare's plays such as "King Lear", "Macbeth", and "Othello" in Kiev and Odessa. When she was in Odessa as a guest of the merchant Nikolai Mironovich Toshkov, she and the other boarding students borrowed and wore the clothes of his wife who owned a rich dress collection. ${ }^{37}$ Another student, Karavelova, also experienced the lifestyle of the well-to-do aristocratic family in Moscow she lived with, such as conversing in French, wearing fashionable outfits, travelling by carriage, and going to spas abroad. ${ }^{38}$

Clothing, however, had not only materialist but also political dimensions. For example, the Serbian writer Jelena Dimitrijević, together with her husband, visited Thessaloniki a month after the Young Turk Revolution started in $1908 .^{39}$ There, she met with several women, especially wives of officers, and enquired about the disposition of women to "unwrap (razviat) themselves" or remove the veil and cover dress. She divided these harem women into two groups: "old" and "new," according to their home location and lifestyle. The "new" ones wore a cover (çarşaf) with a "European cut following the new Parisian fashion" and a scarf (écharpe). She met a woman who had a "coiffure à la dernière mode parisienne" while others used the perfume "Heliotrope" and French makeup. Many houses were huge and filled with European furnishings. Yet both groups—old and new — did not talk on streets and avoided crowded public spaces. ${ }^{40}$ Dimitrijević also visited Gülistan Hanum-a "European educated woman" - who had a European nanny, studied at the American college in Istanbul, spoke six languages, owned European furniture, a piano, and shelves with books in English and French. She was a member of the Committee

36 For instance, Genov's pharmacy in Skopje furnished local middle-class women from multiethnic backgrounds with: "brosse à dents, savon au goudron, milk soap, hair dye, crème Narziss, Ess. Bouquet perfume, viola vernis, lait virginale, one box pink poudre.” Drzhaven Arhiv na Republika Makedonija, Skopje, f. 725, box 2, 45, 181.

37 Kirkovich, Spomeni, 20-23.

38 Karavelova, Spomeni, 21.

39 Hawkesworth, "A Serbian Woman," 68-69.

40 Dimitriević, Pisma, 21-30. 
of Union and Progress and a translator of articles from foreign newspapers. And still none of those harem middle-class women voiced any support for the removal of çarşafs. It was only a few women of humble origin who talked to Dimitrijević on the street and expressed their desire to be free and without any cover. ${ }^{41}$ These impressions further substantiate the thesis that consumption of western goods does not always lead to the adoption of western values. ${ }^{42}$

An interesting example of the clash between traditional rural life and cosmopolitan urban culture is provided in the memoir of Mikhail Madzharov, a late 19th-century Bulgarian politician. On the way to Jerusalem, his family stopped in Constantinople, where his father carried out a business with a Greek partner. The latter invited them to a dancing party at his home. The visit profoundly shocked Madzharov's mother because the Greek women wore low-necked dresses, used makeup, danced and, above all, seemed "free and self-confident and even sometimes with loose morals". ${ }^{43}$ The language used in describing the mother being scandalized is suggestive of the divergent consumption tastes and cultural behaviours within the same merchant milieu. It was through travel that both groups who kept such diverse lifestyles encountered each other.

This story of the cultural gap between Madzharov's mother and her Greek counterparts in the Ottoman capital was not an isolated case. Many articles from the newspapers of the 186os and 1870 s launched furious attacks against crinolines and considered female self-confidence as immoral and ostentatious. ${ }^{44}$ Ironically, women were targeted for "parroting" European fashion during a time when men themselves were dressed in a European manner. ${ }^{45}$ In the case of Greece, which resented its dependence on the Great Powers, the imposition of western behaviour by both the Bavarian court and the diaspora led to the reinforcement of traditional gender roles and morals as a form of

\footnotetext{
41 Dimitriević, Pisma, 38-40, 45, 67, 71.

42 Donald Quataert, "Introduction", in Consumption Studies and the History of the Ottoman Empire 1550-1922, 5.

43 Mikhail Madzharov, "Na Bozhi grob predi 6o godini", in Svetla Giurova and Nadia Danova (eds.), Kniga za bŭlgarskite hadzhii (Sofia: 1995), 47-48.

44 Canner, "Embourgeoisement", 186.

45 Exertzoglou, "The Cultural Uses", 86. There is an interesting connection between the theories of biological evolution and the expansion of critiques of blind fashion imitation that was compared to apes' behaviour ("thoughtless aping of Europeanization"). See Artemis Yagou, "Dress, Modernity and Theories of Biological Evolution in 19th Century Greece", in Constanţa Vintilă-Ghiţulescu (ed.), Traditional Attire to Modern Dress: Modes of Identification, Modes of Recognition in the Balkans (XVIIth-XXth Centuries) (Newcastleupon-Tyne: 2011), 198-206.
} 
resistance to the "cultural hegemony of the West". 46 In the Romanian principalities, attacks against the "corrupting" impact of the West began after the revolutions of $1848 .{ }^{47}$ In a similar manner, the late Ottoman cartoons lampooned women dressed in European fashion, implying that with the "benefits of material culture come economic subservience and social disarticulation". ${ }^{48}$ The 19th-century Ottoman novels also expressed an ambivalent attitude towards European culture and its consumerist aspects by highlighting the character of the young spendthrift. The latter adopted alafranga (western) consumption tastes but with a superficial understanding of European cultural values. ${ }^{49}$ Likewise, Vaka described a visit to the family of an old general in Sofia whose granddaughter she ridiculed: "She had a smattering of French and paraded it shamelessly. She spoke of their eating room as 'our library', because it contained a shelf full of yellow-backed [cheap] French novels." ${ }^{.50}$ Halidé Edib noted the issue of imitation in a less sarcastic manner. In Syria, the rich Christian nobility displayed an Arab imitation of the Parisian world: "Strange to say, they still had something of their own which they tried hard to hide."51 As Haris Exertzoglou reminds us, new consumption patterns provided one of the multiple arenas for shaping and negotiating social identities. ${ }^{52}$ Such examples of appropriation of western material objects, satirized by European travellers or adapted to local settings, show how women conceived of themselves and aspired to belong to an easily identifiable group.

Female garments became not only a symbol of modernity and influence from the West, but mostly a challenge to the patriarchal social order and traditional economy. On the one hand, many traditional craftsmen felt threatened by the increased consumption of imported commodities and, around the

46 Eleni Varikas, "National and Gender Identity in Turn-of-the-Century Greece", in Sylvia Paletschek and Bianca Pietrow-Ennker (eds.), Women's Emancipation Movements in the Nineteenth Century. A European Perspective (Stanford: 2004), 265-266.

47 Angela Jianu, "Women, Fashion, and Europeanization: The Romanian Principalities, 1750-1830," in Amila Buturović and Irvin Cemil Schick (eds.), Women in the Ottoman Balkans. Gender, Culture and History (London: 2007), 203.

48 Palmira Brummett, "Dogs, Women, Cholera, and Other Menaces in the Streets: Cartoon Satire in the Ottoman Revolutionary Press, 1908-11," International Journal of Middle East Studies 2, no. 4 (1995), 448.

49 Suraiya Faroqhi, "Research on the History of Ottoman Consumption: A Preliminary Exploration of Sources and Models," in Consumption Studies and the History of the Ottoman Empire 1550-1922, 21.

5o Vaka, The Heart, 196.

$51 \quad$ Halidé Edib, House, 370-371.

$5^{2}$ Exertzoglou, "The Cultural Uses", 78. 
middle of the century, a new profession appeared, the frenk terzi, a Europeanstyle tailor serving the incipient middle-class taste. On the other hand, the popularity of imported goods stimulated the production of local imitations on such a scale that the shoemaking industry in Istanbul stopped manufacturing traditional footwear and began producing European-style shoes. ${ }^{53}$ Yet, such shifts were gradual and affected mostly urban strata.

Cities also became sites of European educational impact. In the second half of the 19th century, women's education was a subject of extensive debate among Greeks and Bulgarians. ${ }^{54}$ According to Eleni Varikas, women's education was closely interwoven with processes of urbanization, westernization, and the emergence of the fluid category of the middle class. While for men it served as a tool for social mobility, for women, education turned into a form of conspicuous consumption, especially visible among the well-to-do urban stratum. The latter was the group who could afford private secondary education for their daughters because the Greek state did not provide public secondary education. ${ }^{55}$ Diaspora women, too, were expected to attain "cultural skills", such as proficiency in French and music through private lessons, as an expression of their family's status. The same was true for wealthy Muslim families in Istanbul. ${ }^{56}$ Therefore, women's education became both a commodity and a tool for acquiring "European" taste, which involved adoption of cultural habits and material objects.

Moreover, women's education, a form of cultural capital for middle-class women, also had an impact on more traditional forms of consumption: it gradually undermined the importance of dowries. For example, Zrnić studied at the Women's High School in Belgrade and became a teacher. She got married without a dowry. Her aunt was jealous that she was getting an education while her own daughters were not and expressed this sentiment: "They do not need it [education]. Dowries are ready for them, so we'll be able to pick our

53 See the cited literature in Kate Fleet, "The Powerful Public Presence of the Ottoman Female Consumer", in Ebru Boyar and Kate Fleet (eds.), Ottoman Women in Public Space (Leiden: 2016), 117.

54 Alexandra Bakalaki, "Gender-Related Discourses and Representations of Cultural Specificity in Nineteenth-Century and Twentieth-Century Greece", Journal of Modern Greek Studies 12, 1 (May 1994), 77; Krassimira Daskalova, "Bulgarian Women in Movements, Laws, Discourses (1840s-1940s)", Bulgarian Historical Review 1-2 (1999): 180-196.

55 Eleni Varikas, "Subjectivité et identité de genre. L'univers de l'éducation féminine dans la Grèce du XIX"e siècle," Genèses 6 (1991), 29-33.

$5^{6}$ Ioanna Minoglou, "Women and Family Capitalism in Greece, c. 1780s-1940," Business History Review 81 (Autumn 2007), 521-522; Exertzoglou, "The Cultural Uses", 93. 
sons-in-laws without it."57 The few female teachers were not only geographically mobile but also implemented new practices in their teaching and communication with parents. Many of these ideas were adopted during their own studies and impacted women's lifestyles.

\section{Channels for Adopting Consumer Practices}

New expressions of women's visibility and gendered consumption in the Ottoman Empire were diffused by a variety of means, such as contact with foreigners, travel to Europe, western-style shops, diaspora lifestyles, education abroad, advertising, and photography. For example, famous women who visited the Ottoman capital caused a vogue of imitation. One such person was Empress Eugénie, the wife of Napoleon III, whose arrival in 1869 initiated a "craze for everything French". ${ }^{58}$ Women who went to Europe, such as Melek Hanım, also became sources of information about the western way of life. She described the curiosity and thirst for knowledge of the second wife of Sultan Mahmud and sister of Sultan Abdülmecid:

Knowing that I had been in Europe, she interrogated me as to the manners and customs of the Christians, the way the towns were built, the balls, theatres, systems of lighting by gas, architecture of the palaces, and a thousand other matters unknown to Oriental women. ${ }^{59}$

While her remarks are condescending, they are also indicative of the informal ways of exchanging information that shaped consumer taste.

Levantines in the big cities were the first to encounter European visitors to the Ottoman Empire. For example, the type of clothing shops, listed in the Constantinople almanac of 1881 , evidenced that most of the "bijoutiers, couturiers, dessinateurs, modistes, and pelletiers" were either Europeans or nonMuslims. However, as Onur Inal argued, the process of consuming European

$57 \quad$ Irvine and Lilly, Natalija, 47 .

58 Fleet, "The Powerful Public Presence", 116; For more examples, see Anastasia Falierou, "From the Ottoman Empire to the Turkish Republic: Ottoman Turkish Women's Clothing between Tradition and Modernity", in Constanţa Vintilă-Ghiţulescu (ed.), Traditional Attire to Modern Dress: Modes of Identification, Modes of Recognition in the Balkans (XVIIth-XXth Centuries), 180-184. See also Falierou's chapter in this volume. 
fashion and lifestyles was more complex involving borrowing, appropriation, and adaptation. ${ }^{60}$ Elizabeth Frierson also suggested that veneration of western culture went hand-in-hand with resistance and subversion through selection and display of consumer goods in shops ${ }^{61}$ All previously cited women travellers attested to the trend of mixing traditional and western clothing, furnishings, and manners.

In the Ottoman Balkans, male merchants were often in charge of purchasing women's accessories. Several memoirs mention that men were buying female dresses and scarves in Istanbul to show off that they had earned money. The abacıs (producers of rough woollen fabric) that traded in Anatolia would make a special stop in the Ottoman capital to buy clothes for their wives and thus "men introduced female fashions" in Koprivshtitza. ${ }^{62}$ As previously noted, Madzharov's mother's negative reaction to Greek women's fashion in Constantinople, however, showed that their husbands were not too openminded in their tastes. A similar case comes from the Arie brothers, merchants in Samokov, who had an "oral contract" with Mehmed Emin ağa, a local notable. The latter agreed to buy everything he needed for his harem from Avram's dükkân (shop). ${ }^{63}$ The ledger of hacı Khristo Rachkov, a trader in Gabrovo, also discloses expenses for his wife's clothes, such as three fur coats and a dress, upon his return from Jerusalem. ${ }^{64}$ The acquisition of the title hacı (given to pilgrims) meant that he obtained a higher social status, which enabled him to purchase more expensive clothes for his wife. Rada Kirkovich also remembered that during her stay in Constantinople a certain merchant bought clothes for three female students returning from Russia to "look more decently". This occasion allowed them to visit Pera and "all shops and European houses".65

6o Onur Inal, "Women's Fashions in Transition: Ottoman Borderlands and the AngloOttoman Exchange of Costumes", in Constanţa Vintilă-Ghiţulescu (ed.), Traditional Attire to Modern Dress: Modes of Identification, Modes of Recognition in the Balkans (XVIIthXXth Centuries), 162-167. See also Charlotte Jirousek, "The Transition to Mass Fashion System Dress in the Later Ottoman Empire", in Consumption Studies and the History of the Ottoman Empire 1550-1922, 227-228.

61 Elizabeth B. Frierson, "Cheap and Easy: The Creation of Consumer Culture in Late Ottoman Society", in Consumption Studies and the History of the Ottoman Empire 1550$1922,246$.

62 Mikhail Madzharov, Spomeni (Sofia: 1968), 210.

63 Mizei Samokov-Nauchen Arkhiv, Inv. No. 11, a.e. 1, 51-52.

64 Evguenia Davidova, Balkan Transitions to Modernity and Nation-States through the Eyes of Three Generations of Merchants (1780s-189os) (Leiden: 2013), 191-192.

65 Kirkovich, Spomeni, 24. 
Not surprisingly, advertising in Bulgarian newspapers in the 1860 and 1870 s was targeting men even when the commodity was intended for women. ${ }^{66}$ While such examples are reminiscent of Thorstein Veblen's concept of "conspicuous consumption", the picture was more nuanced. Respectively, concerns were voiced that a husband's consent to buying luxurious items not only ruined the family's budget, but also elevated and reversed the position of women in the decision-making process within the family. ${ }^{67}$ The above-mentioned cases, referring to small provincial towns, though, do not seem to corroborate such patriarchal angst. In fact, they reduce female agency to consumption filtered through male perceptions of respectability. Dora d'Istria, a cosmopolitan European aristocrat of Albanian origin, also criticized women in the district of Laconia because they danced national dances and wore crinolines with fezzes on their heads. The latter addition to their "elegance" was attributed to their husbands' requests. ${ }^{68}$

Contact with diaspora merchants constituted another channel for transmitting fashionable trends and manners, especially in bigger urban centres. As Ioanna Minoglou has argued, not only businessmen but also women in Greece "looked to the diaspora for inspiration". ${ }^{69}$ Residents of Constantinople emulated the diaspora's cosmopolitan lifestyle. On a provincial level, the Russian Karlova described middle-class women with exposure to European material culture in Ohrid. She depicted her hostess, the wife of a local merchant, as "quite a charming young Bulgarian kokona (dama), well-dressed in a European garb" ${ }^{70}$ This is a good example of what Alan Hunt called "vicarious consumption", the trickling down of fashion from upper to lower strata. ${ }^{71}$ However, this picture of top-down change is more complicated. For instance, the Tanzimat (1839-1876), the period of modernization in the Ottoman Empire, among other reforms, introduced a new dress code for men. As men began to follow the state regulations requiring European dress, women, who were outside the purview of the state, also experimented with such garments. ${ }^{72}$

Moreover, upon their return from studies abroad, many women brought new social manners, especially with respect to leisure. Such was the case of Karavelova who rode a horse borrowed from the wife of a French engineer in

\footnotetext{
66 Ivan Ilchev, Reklamata prez Vŭzrazhdaneto (Sofia: 1995),189.

67 Exertzoglou, "The Cultural Uses", 88.

68 Dora d'Istria, Excursions en Roumélie et en Morée, Vol. 1 (Zurich: 1863), 554-555.

69 Minoglou, "Women", 527.

$70 \quad$ Karlova, "Turetzkaya provintziya", no. 4 (1870): 181.

71 Cited in Jirousek, “The Transition to Mass Fashion”, 226.

72 Jirousek, "The Transition to Mass Fashion", 228.
} 
the town of Russe. This behaviour did not pass unnoticed and the local newspaper criticized the new teacher who "spreads debauchery by riding a horse and using makeup".73 She also started teaching other women Russian and French, and dances such as the waltz and mazurka. ${ }^{74}$ The issue of women's consumption is broader, though, and reflects discourses on gender, education, motherhood, and nationalism. In Greece, for example, there existed two opposing, but nonetheless, negative stereotypes: the illiterate, backward woman and the girls' school graduate, who was "conceited, frivolous, vain, full of useless knowledge, forever parroting foreign modes, of suspect sexual morality, and, of course, highly unreliable as a mother". ${ }^{75}$

Women teachers worked diligently to change the perception of education, hygiene, and motherhood. In her Avtobiografia, Anastasia Tosheva wrote that "A lot of effort was needed to fight against the prejudice that women can do without education. It was necessary to convince primarily the mothers in its usefulness." Tosheva received a Russian state scholarship and studied at a boarding school for girls that belonged to the lesser nobility in Odessa. As a teacher in Stara Zagora in the 186os, she used to invite her students' mothers to the school to re-read and re-interpret the Gospel after the church service. These meetings were accompanied by a short lecture about women's education and child-rearing. ${ }^{76}$ Similarly, after she had to cut her students' hair very short because of lice, the Serbian teacher Natalija Zrnić began lecturing the mothers on issues such as hygiene, household chores, and childcare. ${ }^{77}$ Even though her actions incurred the wrath of the parents in the village of Topola, this example shows how attempts at implementing local changes were inspired by knowledge acquired during female teachers' formative years. Both these cases promote not only women's education and modern hygiene, but also notions of respectability embedded in family and marriage.

Women's consumption was also shaped by the rise of the press and photography. Newspapers, such as Hanımlara Mahsuz Gazete (1895-1908), displayed advertisements for European season-specific fashion for young and

73 Karavelova, Spomeni, 64-65.

74 Karavelova, Spomeni, 71.

75 Bakalaki, "Gender-Related Discourses", 81.

76 Tosheva, Avtobiografia, 14-15. She promoted female education "in the name of the nation" and progress. She may have been influenced by her education in Russia and missionary ideas about the status of women in society to pioneer the debate on the "woman question" in the 1860s. See Barbara Reeves-Ellington, "A Vision of Mount Holyoke in the Ottoman Balkans: American Cultural Transfer, Bulgarian Nation-Building and Women's Education Reform, 1858-1870", Gender \& History 16, no. 1 (April 2004), 158-159. Irvine and Lilly, Natalija, 50-51. 
middle-aged women, and children. ${ }^{78}$ The Gazete was the longest lasting women's journal in the Ottoman Empire and, like its Greek counterpart Ladies' Journal (1887-1907), it was read by a multiethnic audience. Among Bulgarian women, Zornitsa (1864-1871), a Protestant missionary magazine, became popular. Its attraction was derived from its focus on women's duties and an emphasis on the mother's role as "nurturer and teacher", both conceived of as a national task. ${ }^{79}$ In other Bulgarian newspapers, the "European origin" of most advertised commodities or services was underscored. ${ }^{80}$ When it comes to photography, in the $186 \mathrm{os}$, one could read sporadic advertisements about women photographers who offered to take pictures in local harems. ${ }^{81}$ By the 188 os, though, family portraits, especially among the Muslim upper class, were a common occurrence and younger women from that group were often photographed without a veil and in European garb. ${ }^{82}$

Another channel for spreading information about material acquisitiveness was provided through women pedlars (bohçacı kadın) who sold linen, apparel, and services. ${ }^{83}$ As Frierson has suggested, this old form of distribution continued within the evolution of new forms of merchandising. ${ }^{84}$ Thus, elements of the intermixing of the European and the local could be traced at all levels of production, distribution, and consumption. Despite the penetration of various new practices, the patriarchal culture remained prevalent; many women fought hard against it, and tried to dissuade their compatriots from harbouring traditional views.

\section{Shifting Perceptions of Women's Roles}

Most foreign women travellers to the Balkans described women's position as undervalued and submissive. D'Istria eloquently articulated the issue of gender discrimination as the "Asiatic prejudices that reign in the peninsula against our sex". 85 Walker also noted the discrepancy between European gender

\footnotetext{
78 Fleet, "The Powerful Public Presence", 117-118.

79 Barbara Reeves-Ellington, Domestic Frontiers. Gender, Reform, and American Interventions in the Ottoman Balkans and the Near East (Amherst: 2013), 82-87.

8 Ilchev, Reklamata, 168.

81 Dunav, II, N 105, 4 August 1865. Cited in Ilchev, Reklamata, 105-106.

82 Suraiya Faroqhi, Subjects of the Sultan. Culture and Daily Life in the Ottoman Empire (London: 2007), 258.

83 Faroqhi, Subjects, 113.

84 Frierson, "Cheap and Easy", 256.

85 Dora d'Istria, Des femmes par une femme, Vol. 2 (Paris: 1865), 124.
} 
superiority based on class, education, and manners and women's treatment. For example, she depicted the Jewish "aristocracy" in Salonica (Thessaloniki) as having:

... higher position in society than their brethren of Constantinople, for which they are perhaps partly indebted to the elegant refinement of their wives. Most of the fair Jewesses are from Florence. They are lovely, accomplished women, their houses are filled with every luxury which art and taste can furnish, and their dresses might excite the envy of many Parisian elegante, but yet their lives can rarely be happy. They are betrothed in infancy, and afterwards married to men in every way inferior to themselves, and often of double their own age; men of little education, and few ideas beyond the accumulation of wealth, and whose treatment of their young wives is said to be frequently the reverse of gentle. ${ }^{86}$

If Walker wrote about the accomplished yet unhappy lives of Jewish women in Salonica, Karlova, on her part, was critical of "Turkish ladies (madamy)", because they "lead life in complete idleness and they cannot read and write". ${ }^{87}$ Her attention to literacy probably reflected the essence of the Russian "woman question" in its early phase, namely the education of women. ${ }^{88}$

In the Balkans, however, nationalism permeated the discourse of women's education. In Greece, the philanthropist, the teacher, and the writer were the publicly accepted vocations for middle-class women at the turn of the 19th century; all these pursuits were intimately related to the concept of patriotic motherhood during a time when women constituted the category of "noncitizens", bound by duties but without rights. ${ }^{89}$ Consequently, their education became an important battleground between arguments about tradition and calls for progress and modernization. These new meanings of patriotic motherhood, however, both legitimized and undermined the male-dominated public space. Therefore, most educated women expressed support for women's

86 Walker, Through Macedonia, 57-58.

87 Karlova, "Turetzkaya provintziya", no. 3 (1870), 751.

88 Richard Stites, The Women's Liberation Movement in Russia. Feminism, Nihilism, and Bolshevism 1860-1930 (Princeton: 1991), 30.

89 Efi Avdela, "Between Duties and Rights: Gender and Citizenship in Greece, 1864-1952", in Faruk Birtek and Thalia Dragonas (eds.), Citizenship and the Nation-State in Greece and Turkey (London: 2005), 117-122. On legal rights see also Evdoxios Doxiadis, The Shackles of Modernity. Women, Property, and the Transition from the Ottoman Empire to the Greek State (1750-1850) (Cambridge: 2011), 179-255. 
education charged with a social and national mission. The importance of education solidified the perception of women teachers as significant actors in the nationalist discourse and provided new opportunities for them to find support among a larger segment of the population. Leading Bulgarian journalists, such as Petko Slaveikov and Liuben Karavelov, wrote multiple articles in support of women's education, while in Greece women's teaching in the unredeemed territories was highly encouraged. ${ }^{90}$ Thus, women's education was valourized within the framework of nationalism and to a much lesser degree as an emancipating project.

Along those lines, Walker was critical of Greek treatment of pre-marital girls. She wrote that "amongst old-fashioned Greek families" girls were kept in seclusion: they stopped attending school after the age of twelve or fourteen, they did not go abroad, and they did not go to church more than two times a year. Thus, this "complete imprisonment" made them look forward to early marriage as the "only hope of emancipation". ${ }^{91}$ Some researchers echo criticism of this mode of confinement, especially with reference to middle-class families in Greece. ${ }^{92}$ The phenomenon of the "separate sphere" involved class, gender, and notions of domesticity, which became mutually constitutive in the formation of middle-class identity. ${ }^{93}$ Natalija Zrnić's diary also illustrates how Serbian middle-class women embraced the cult of domesticity: "When we started we had nothing but our enduring and sincere love for each other, and thank God we now have everything we need." ${ }^{94}$ She valued meritocracy, upward social mobility, and material accumulation at the expense of her gender opportunities and individual freedom. The internalization of the "separate sphere" mentality could also be seen in the previously cited letter by Kirkovich from Russia, another middle-class mobile and educated woman, who wrote with a sense of pride about managing housework and domestic consumption.

Yet the "woman question" or the critique of conditions for women from within, was expressed in several letters "sent" from Thessaloniki by Jelena

9o Krassimira Daskalova, ed. Ot siankata na istoriata: Zhenite $v$ bŭlgarskoto obshtestvo $i$ kultura (1840-1940), (Sofia: 1998), 43-65; Eleni Varikas, I exegersi ton kyrion. I genesi mias pheministikis syneidisis stin Ellada 1833-1907 (Athens: 1987), 97-103, 182-188.

$91 \quad$ Walker, Through Macedonia, 257-258.

92 Varikas, "Subjectivité", 33. Recent research, though, nuances that picture and demonstrates that women exercised much more influence. See Evdoxios Doxiadis, "Women, Wealth, and the State in Greece (1750-186o)", in Evguenia Davidova (ed.) Wealth in the Ottoman and Post-Ottoman Balkans: A Socio-Economic History (London: 2016), 19.

93 Leonore Davidoff and Catherine Hall, Family Fortunes. Men and Women of the English Middle Class 1780-1850, Rev. ed. (London: 2002), 30.

94 Irvine and Lilly, Natalija, 97. 
Dimitrijević. As noted before, she went there to explore whether women wanted to liberate themselves by removing their veils. When talking to various women-mostly middle-class wives of Young Turks' officers-she was struck by the dissonance between their European education and possession of western goods, and their conservative desire to maintain the status quo. Furthermore, Dimitrijević was told that the idea for women's liberation, as a corollary to the restoration of the Constitution, came from foreigners. She felt sad because she could not do anything to help "our Muslim sisters" who were subjugated and on whom their husbands imposed only duties. ${ }^{95}$ As a feminist, Dimitrijević was disappointed by the women's reluctance to seize the political opportunity to achieve gender-based gains.

Other early feminists, such as Sotiria Cléoménous-Alibertis, a transnational teacher and one of the founders of the first feminist magazine Ladies'Journal (1887-1907) in Greece, offer an example of how teaching could be turned into a breadwinning profession. She spent her life travelling between three capitals: Athens, Constantinople, and Bucharest. She and her colleagues illustrate the possibilities of geographical and social mobility that established a transbalkanic gender network and fostered professional identity as autonomous wage earners. It was in their capacity as independent working women that they were able to insert themselves within the helenophone elite in Istanbul. ${ }^{96}$

The "woman question", though, had multiple facets and many women were involved in redefining the notion of domesticity in the social space by appropriating and reproducing the tropes of nationalism and progress. ${ }^{97} \mathrm{Efi}$ Kanner analyzed the emergence of a "philanthropically conceived education" and its politicization during the second half of the 19th century in the Ottoman Empire. Middle-class women tried to assert themselves in the field of civil society, what Kanner called the "respectable public sphere", by forming associations that promoted education, jobs, health, hygiene, and philanthropy. ${ }^{98}$ While travelling and living abroad, many women became familiar with organizations, aimed at furthering civic goals and general prosperity, and transferred such experiences to home. For example, Karavelova, as a student in Moscow, kept the correspondence of her female benefactor who chaired several philanthropic organizations. This early exposure stimulated her later to participate

\footnotetext{
95 Dimitrijević, Pisma iz Soluna, 51.

96 Canner, "Embourgeoisement", 175-199. Kanner, Emphyles koinonikes diekdikiseis, 53-178.

97 Exertzoglou, "The Cultural Uses", 86.

98 Efi Kanner, "From 'the Sick,' 'the Blind' and 'the Crippled' to the Nation of 'Toiling People': Visions of the Poor in the Late Ottoman Empire and the Early Turkish Republic", in Wealth in the Ottoman and Post-Ottoman Balkans: A Socio-Economic History, 126-132.
} 
in numerous Bulgarian and international women's associations. ${ }^{99}$ Similarly, Filaretova was impressed by a homeless shelter in Moscow and donated money for building such an institution in Sofia. ${ }^{100}$

The proliferation of various female societies and clubs absorbed some of the donations that would have otherwise gone to the church during the first third of the 19th century. ${ }^{101}$ Thus, wills from this period showed bequests going to monasteries, orphanages, schools, and charities organized by the church. ${ }^{102}$ In the second half of the century, however, the structure of donations changed and refocused on secular sociability that impacted consumer behaviour. Middle-class women, such as Dimitrijević and Zrnić, participated in associations not only in their ethno-national communities, but also in multiethnic ones, such as Kirkovich. In 1878, when the autonomous province of Eastern Rumelia was established, the latter moved to its capital as a teacher and was consequently elected secretary of the new philanthropic association, which consisted of "women of all nationalities". ${ }^{103}$ Even though women's social organizations actively supported local initiatives to promote education, jobs, hygiene, and the alleviation of poverty, most of those societies did not challenge the ideology of domesticity and bourgeois respectability. For instance, Halidé Edib's memoir described the establishment of the first Turkish women's club, in 1912, in Istanbul. The founders were teachers and "some educated Turkish women" and the club promoted the cultivation of its members by offering lessons in French, English and Turkish, and classes in domestic science and childrearing. Despite having a "feministic tendency", the club remained well within the bounds of philanthropy and pragmatism. ${ }^{104}$ Similarly, as Carol Harrison argued, associations in France, both in practical and rhetorical terms, drew the boundaries of the new bourgeoisie and secured the transition from the ancien régime to the post-revolutionary society. Moreover, the gendering of the middle class happened mainly through cultural practices, including consumer

99 Karavelova, Spomeni, 41.

100 Tsekov, Iordanka Filaretova, 140-145.

101 There were 61 women's organizations, founded between 1857-1878, in present-day Bulgaria. Margarita Cholakova, "Mezhdunarodni kontakti na bŭlgarskite zhenski druzhestva (1857-1878)", in Krassimira Daskalova and Raina Gavrilova (eds.), Granitsi na grazhdanstvoto: evropeiskite zheni mezhdu traditsiata i modernostta (Sofia: 2001), 108; Kirkovich, Spomeni, 43 .

102 See, for instance, the will of Irina, who donated 1,870 kuruş in 1789. Davidova, Balkan Transitions to Modernity, 124.

103 Hawkesworth, “A Serbian Woman”, 72; Irvine and Lilly, Natalija, 107; BIA-NB KM, f. 22, a.e. 886, pp. 48-49. Rada Kirkovich to Maria Naidenova, 1 October 1878.

104 Halidé Edib, House, 275-276. 
behaviour and sociability, which were also constitutive parts of the new social hierarchy. ${ }^{105}$

\section{Conclusion}

In sum, I assigned consumer agency to individual middle-class women travellers and presented the social impact they had on conceptualizing the respectable family model, national education, and public gender visibility. Such cases were not isolated and indicate parallels to similar trends in the rest of Europe. As Leora Auslander has suggested, in the long 19th century, women's consumption passed through three "stages" which also coexisted. In the first half of the century, consumption revolved around the constitution and representation of the family and class. Around the 185 os, references to the nation were emphasized, and towards the 1880 s, consumer identity construction was refocused on the self. ${ }^{106}$

This chapter proposed expanding the notion of "consumption as a literal act" by examining elements in the "commodification of culture as a process". ${ }^{107}$ The increased mobility of 19th-century society, a quintessential characteristic of modernity, became commodified. Balkan women travellers tried both to emulate and to adapt some of the ideas, manners, and material objects they attained through their travels and promoted tastes and behaviours that allowed for the repackaging of traditional and modern duties, often at the expense of women's rights. Therefore, notions of respectability both upheld the status quo and promoted cultural and moral change that gradually undermined patriarchy. It was the next generation that embraced the political and social justice aspects of the "woman question".

As it has been argued elsewhere, the meanings of cultural identity are the result of a long process of interethnic contacts, mutual influences, and multilingualism. Westernization played a dual role that not only triggered nationalism but also contributed to some homogenization. ${ }^{108}$ It is at the nexus of those two processes - convergence and divergence - that consumption can be situated. This chapter focused on a transitional period when the formation of the regional middle classes was in the making, in tandem with urbanization and

105 Harrison, The Bourgeois Citizen, 3, 8.

106 Leora Auslander, "The Gendering of Consumer Practices", 79.

107 Roberts, “Gender", 843.

108 Raymond Detrez \& Pieter Plas (eds.), Developing Cultural Identity in the Balkans. Convergence vs. Divergence (Brussels: 2005), 13-14. 
modernization. Those socio-economic and cultural processes were politicized, secularized, and glued together by nationalism. The adoption of new ideas, practices, and goods, many of them disseminated through travel, allowed educated women to insert themselves into both the public and private spheres and the grey areas in between.

\section{Acknowledgment}

I am grateful to the anonymous reviewers for their very helpful comments and suggestions.

\section{Bibliography}

Appadurai, Arjun, (ed.), The Social Life of Things: Commodities in Cultural Perspective (Cambridge: 1986).

Appleby, Joyce, "Consumption in Early Modern Social Thought", in John Brewer and Roy Porter (eds.), Consumption and the World of Goods (London: 1993), 162-173.

Auslander, Leora, "The Gendering of Consumer Practices in Nineteenth-Century France", in Victoria de Grazia and Ellen Furlough (eds.), The Sex of Things: Gender and Consumption in Historical Perspective (Berkeley: 1996), 79-112.

Avdela, Efi, "Between Duties and Rights: Gender and Citizenship in Greece, 1864-1952", in Faruk Birtek and Thalia Dragonas (eds.), Citizenship and the Nation-State in Greece and Turkey (London: 2005), 117-143.

Bakalaki, Alexandra, "Gender-Related Discourses and Representations of Cultural Specificity in Nineteenth-Century and Twentieth-Century Greece", Journal of Modern Greek Studies, 12, no. 1 (May 1994), 75-106.

Bracewell, Wendy, "Travels Through the Slav World", in Wendy Bracewell and Alex Drace-Francis (eds.), Under Eastern Eyes: A Comparative Introduction to East European Travel Writing on Europe (Budapest: 2008), 147-194.

Bracewell, Wendy (ed.), Orientations. An Anthology of East European Travel Writing, ca. 1550-200o (Budapest: 2009).

Bracewell, Wendy and Alex Drace-Francis, (eds.), Balkan Departures. Travel Writing from Southeastern Europe (New York: 2009).

Brewer, John and Roy Porter, "Introduction", in John Brewer and Roy Porter (eds.), Consumption and the World of Goods (London: 1993), 1-15.

Brummett, Palmira, "Dogs, Women, Cholera, and Other Menaces in the Streets: Cartoon Satire in the Ottoman Revolutionary Press, 1908-11", International Journal of Middle East Studies 27, no. 4 (1995), 433-460. 
Canner, Efi, "Embourgeoisement, réseaux sociaux et identitiés de genre dans les Balkans de la deuxième moitié du XIX $\mathrm{X}^{\mathrm{e}}$ siècle. Le cas de Sotiria CléoménousAlibertis", Turcica 39 (2007), 175-199.

Cazacu, Matei, Des Femmes sur les routes de l'Orient. Le voyage à Constantinople au XIX $X^{e}$ siècle (Genève: 1999).

Cholakova, Margarita, "Mezhdunarodni kontakti na bŭlgarskite zhenski druzhestva (1857-1878)", in Krassimira Daskalova and Raina Gavrilova (eds.), Granitsi na grazhdanstvoto: evropeiskite zheni mezhdu traditsiata i modernostta, (Sofia: 2001), 108-120.

Daskalova, Krassimira, "Bulgarian Women in Movements, Laws, Discourses (1840s1940s)", Bulgarian Historical Review 1-2 (1999): 180-196.

Daskalova, Krassimira (ed.), Ot siankata na istoriata: Zhenite $v$ bŭlgarskoto obshtestvo $i$ kultura (1840-1940), (Sofia: 1998).

Davidoff, Leonore and Catherine Hall, Family Fortunes. Men and Women of the English Middle Class 1780-1850, Revised Edition (London: 2002).

Davidova, Evguenia, Balkan Transitions to Modernity and Nation-States through the Eyes of Three Generations of Merchants (1780s-189os) (Leiden: 2013).

Davidova, Evguenia, “Gender and Culture in the Turkish Province: The Observations of a Russian Woman Traveler (1868)", Aspasia. 6 (2012), 79-95.

Detrez, Raymond \& Pieter Plas (eds.), Developing Cultural Identity in the Balkans. Convergence vs. Divergence (Brussels: 2005).

Dimitrijević, Jelena, Pisma iz Soluna/Epistoles apo ti Thessaloniki, eds. Dejan Aničić and Vladimir Bošković (Lozniza: 2008).

Doxiadis, Evdoxios, “Women, Wealth, and the State in Greece (1750-186o)", in Evguenia Davidova (ed.), Wealth in the Ottoman and Post-Ottoman Balkans: A Socio-Economic History (London: 2016), 9-29.

Doxiadis, Evdoxios, The Shackles of Modernity. Women, Property, and the Transition from the Ottoman Empire to the Greek State (1750-1850) (Cambridge: 2011).

Drenkova, Fani, Comp., Kato antichna tragedia. Sŭdbata na Ekaterina Karavelova $i$ neinoto semeistvo v pisma, dnevnitsi, fotografia (Sofia: 1984).

d'Istria, Dora, Excursions en Roumélie et en Morée, Vol. 1 (Zurich: 1863).

d'Istria, Dora, Des femmes par une femme, Vol. 2 (Paris: 1865).

de Grazia, Victoria and Ellen Furlough (eds.), The Sex of Things: Gender and Consumption in Historical Perspective (Berkeley: 1996).

Exertzoglou, Haris, "The Cultural Uses of Consumption: Negotiating Class, Gender, and Nation in the Ottoman Urban Centers during the 19th Century", International Journal of Middle East Studies 35 (2003), 77-101.

Falierou, Anastasia, "From the Ottoman Empire to the Turkish Republic: Ottoman Turkish Women's Clothing between Tradition and Modernity”, in Constanța VintilăGhițulescu (ed.), Traditional Attire to Modern Dress: Modes of Identification, Modes 
of Recognition in the Balkans (XVIIth-XXth Centuries) (Newcastle-upon-Tyne: 2011), 175-192.

Faroqhi, Suraiya, Subjects of the Sultan. Culture and Daily Life in the Ottoman Empire (London: 2007).

Faroqhi, Suraiya, "Research on the History of Ottoman Consumption: A Preliminary Exploration of Sources and Models", in Donald Quataert (ed.), Consumption Studies and the History of the Ottoman Empire 1550-1922. An Introduction (New York: 2000), 15-44.

Fleet, Kate, "The Powerful Public Presence of the Ottoman Female Consumer", in Ebru Boyar and Kate Fleet (eds.), Ottoman Women in Public Space (Leiden: 2016), 91-128.

Frierson, Elizabeth B., "Cheap and Easy: The Creation of Consumer Culture in Late Ottoman Society," in Donald Quataert (ed.), Consumption Studies and the History of the Ottoman Empire 1550-1922. An Introduction (New York: 2000), 243-26o.

Gallant, Thomas, "Long Time Coming, Long Time Gone: The Past, Present and Future of Social History", Historein 12 (2012), 9-20.

Harrison, Carol E., The Bourgeois Citizen in Nineteenth-Century France. Gender, Sociability, and the Uses of Emulation (Oxford: 1999).

Hawkesworth, Celia, "A Serbian Woman in a Turkish Harem: The Work of Jelena Dimitrijević (1862-1945)", The Slavonic and East European Review 77, no. 1 (Jan., 1999), 56-73.

Ilchev, Ivan, Reklamata prez Vŭzrazhdaneto (Sofia: 1995).

Inal, Onur, "Women's Fashions in Transition: Ottoman Borderlands and the AngloOttoman Exchange of Costumes”, in Constanța Vintilă-Ghițulescu (ed.), Traditional Attire to Modern Dress: Modes of Identification, Modes of Recognition in the Balkans (XVIIth-XXth Centuries) (Newcastle-upon-Tyne: 2011), 144-174.

Irvine, Jill A. and Carol S. Lilly (eds.), Natalija. Life in the Balkan Powder Keg, $1880-1956$ (Budapest: 2008).

Jianu, Angela, "Women, Fashion, and Europeanization: The Romanian Principalities, 1750-1830", in Amila Buturović and Irvin Cemil Schick (eds.), Women in the Ottoman Balkans. Gender, Culture and History (London: 2007), 201-230.

Jirousek, Charlotte, "The Transition to Mass Fashion System Dress in the Later Ottoman Empire," in Donald Quataert (ed.), Consumption Studies and the History of the Ottoman Empire 1550-1922. An Introduction, (New York: 2000), 201-241.

Kanner, Efi, 'From 'the Sick', 'the Blind', and 'the Crippled' to the Nation of 'Toiling People': Visions of the Poor in the Late Ottoman Empire and the Early Turkish Republic", in Evguenia Davidova (ed.), Wealth in the Ottoman and Post-Ottoman Balkans: A Socio-Economic History (London: 2016), 117-136.

Kanner, Efi, Emphyles koinonikes diekdikiseis apo tin Othomaniki autokratoria stin Ellada kai stin Tourkia. O kosmos mias ellinidas christianis daskalas (Athens: 2012).

Karavelova, Ekaterina, Spomeni na Ekaterina Karavelova (Sofia: 1984). 
Karlova, M., “Turetzkaya provintziya," Vestnik Evropȳ 5, no. 3 (1870): 721-751; no. 4 (1870), 150-190.

Kirkovich, Rada, Spomeni (Sofia: 1927).

Köksal, Duygu, "Escaping to Girlhood in Late Ottoman Istanbul: Demetra Vaka's and Selma Ekrem's Childhood Memories", in Benjamin Fortna (ed.), Childhood in the Late Ottoman Empire and After (Leiden: 2016), 250-274.

Madzharov, Mikhail, "Na Bozhi Grob predi 60 godini", in Svetla Giurova and Nadia Danova (eds.), Kniga za bŭlgarskite hadzhii (Sofia: 1995), 31-75.

Madzharov, Mikhail, Spomeni (Sofia: 1968).

Melek Hanım, Thirty Years in the Harem; or, the Autobiography of Melek-Hanum, Wife of H. H. Kibrizli-Mehemet-Pasha (New York: 1872).

Melman, Billie, "Desexualizing the Orient: The Harem in English Travel Writing by Women, 1763-1914", Mediterranean Historical Review 4, no. 2 (December 1989), 301-339.

Minoglou, Ioanna, "Women and Family Capitalism in Greece, c. 1780s-1940", Business History Review 81 (Autumn 2007), 517-538.

Mitsi, Efterpi, "Lady Elizabeth Craven's Letters from Athens and the FemalePicturesque", in Vassiliki Kolocotroni and Efterpi Mitsi (eds.), Women Writing Greece. Essays on Hellenism, Orientalism and Travel (Amsterdam: 2008), 19-37.

Quataert, Donald, “Introduction”, in Donald Quataert (ed.), Consumption Studies and the History of the Ottoman Empire 1550-1922. An Introduction (New York: 2000), 1-13.

Reeves-Ellington, Barbara, Domestic Frontiers. Gender, Reform, and American Interventions in the Ottoman Balkans and the Near East (Amherst: 2013).

Reeves-Ellington, Barbara, "A Vision of Mount Holyoke in the Ottoman Balkans: American Cultural Transfer, Bulgarian Nation-Building and Women's Education Reform, 1858-1870", Gender \& History 16, no. 1 (April 2004): 146-171.

Roberts, Mary Louise, “Gender, Consumption, and Commodity Culture", The American Historical Review 103, no. 3 (Jun., 1998), 817-844.

Stites, Richard, The Women's Liberation Movement in Russia. Feminism, Nihilism, and Bolshevism 1860-1930 (Princeton: 1991).

Tosheva, Anastasia, Avtobiografia (Stara Zagora: 1911).

Tsekov, Khristo, Iordanka Filaretova Gospozhata (Sofia: 2009).

Vaka, Demetra (Mrs. Kenneth-Brown), The Heart of the Balkans (Boston: 1917).

Varikas, Eleni, "National and Gender Identity in Turn-of-the-Century Greece", in Sylvia Paletschek and Bianca Pietrow-Ennker (eds.), Women's Emancipation Movements in the Nineteenth Century. A European Perspective (Stanford: 2004), 263-279.

Varikas, Eleni, "Subjectivité et identité de genre. L'univers de l'éducation féminine dans la Grèce du XIX è siècle," Genèses 6 (1991), 29-51.

Varikas, Eleni, I exegersi ton kyrion. I genesi mias pheministikis syneidisis stin Ellada 1833-1907 (Athens: 1987). 
Vickery, Amanda, "His and Hers: Gender, Consumption and Household Accounting in Eighteenth-Century England," Past and Present (2006) Supplement (Vol. 1), 12-38. Walker, Mary Adelaide, Through Macedonia to the Albanian Lakes (London: 1864). Yagou, Artemis, "Dress, Modernity and Theories of Biological Evolution in 19th Century Greece”, in Constanța Vintilă-Ghițulescu (ed.), Traditional Attire to Modern Dress: Modes of Identification, Modes of Recognition in the Balkans (XVIIth-XXth Centuries) (Newcastle-upon-Tyne: 2011), 194-211.

Yannitsiotis, Yannis, "Social History in Greece: New Research on Class and Gender", East Central Europe 34, no. 1-2 (2007): 105-138. 